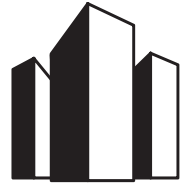

УДК 352

doi: $10.15421 / 1520177$

\section{Свропейські практики забезпечення дісвості інститутів самоорганізації населення в контексті надання суспільних послуг}

\section{Т.В. Серьогіна}

seregina.dridu@gmail.com

Дніпропетровський регіональний інститут державного управління Національної академї державного управління при Президентові Украӥни, 49044, Дніпро, вул. Гоголя, 29

Встановлено, що країни Європи багато уваги приділяють необхідності забезпечення дієвості інститутів самоорганізації населення, адже останні як виразники суспільних проблем, можуть 3 ними найкращим чином упоратися, в першу чергу це робиться шляхом надання суспільних послуг. Особливістю європейських практик $€$ історично закладені традиції надання суспільних послуг конфесійними організаціями, які таким чином реалізують свою місію в суспільстві. Трансформації в частині суб'єкта-надавача суспільних послуг відбулися коли формувалося поняття «держави добробуту» й держава взяла на себе відповідальність за сферу суспільних послуг. Грунтуючись на досвіді надання суспільних послуг органами публічної влади, почалося формування нових підходів до змісту суб' єкта сфери суспільних послуг. Найбільш поширеним на сьогоднішній день $є$ залучення до цього процесу інститутів самоорганізації населення, хоча це не єдиний механізм їхньої співпраці з публічним сектором. Інший механізм - це фінансування статутної діяльності, що традиційно склалося в Україні. Проте, крізь призму реалізації на практиці принципу субсидіарності та інших елементів процесу децентралізації, забезпечення дієвості інститутів самоорганізації населення, виглядає доцільним запровадження на вітчизняному грунті європейського досвіду в контексті їхнього залучення до сфери надання суспільних послуг. За результатами проведеного дослідження сформульовано основні складові механізму забезпечення дієвості інститутів самоорганізації населення у сфері надання публічних послуг: субсидіювання статутної діяльності; делегування послуг; нормативне закріплення; визнання статусу суспільно корисних; обмеження термінів угод. Визначено, що подальшого наукового опрацювання потребують елементи механізму забезпечення дієвості інститутів самоорганізації населення у сфері надання публічних послуг у частині визначення вимог щодо імплементації усталених європейських практик у діяльність вітчизняних органів публічного управління і адміністрування.

Ключові слова: суспільні послуги; співпраця; публічна влада; фінансування інститутів самоорганізації населення

\title{
European practices of providing of efficiency of self-organizations institutions of population in the context of public services
}

\author{
T.V. Serohina \\ seregina.dridu@gmail.com \\ Dnipropetrovsk regional institute of public administration of National academy \\ for public administration under the President of Ukraine \\ 29, Hoholya St., Dnipro, 49044, Ukraine
}

The research revealed that European countries devote sufficient attention to ensuring the effectiveness of the institutions of self-organization in the context of their public services. The most common areas where they operate

Цитування даної статті: Серьогіна Т.В. Європейські практики забезпечення дієвості інститутів самоорганізації населення в контексті надання суспільних послуг / Т.В. Серьогіна // Аспекти публічного управління. 2017. - T. 5. - № 3-4(41-42). - C. 36-42.

Citation of this article: Serohina, T.V., 2017. Yevropeys'ki praktyky zabezpechennya diyevosti instytutiv samoorhanizatsiyi naselennya $\mathrm{v}$ konteksti nadannya suspil'nykh posluh [European practices of providing of efficiency of self-organizations institutions of population in the context of public services]. Public administration aspects 5 , 3-4(41-42), 36-42. doi: 10.15421/1520177 (in Ukrainian).

Peer-reviewed, approved and placed: 22.03 .17 
are a system of health, education and assistance during emergencies. The study showed that in the development of public services, there were significant transformations in terms of subject-provider. Historically it was confessional organizations working on a voluntary basis, and linked their activity with the realization of Christian mission. Subsequently, when there had been formation of a «welfare state», the state took over responsibility for the area of public services. In favor of institutions of self-organization has been a change in the system when it became clear that they are best in the provide public services, especially in the social sphere, because they are the demonstrating of social needs. The main mechanisms of cooperation between institutions of self-organization and the public sector are, first, subsidies for statutory activities of the organization. Another mechanism is delegating services or outsourcing and in this case contracts mostly are for one year with possibility of further extension. In addition there is auxiliary element of providing of effectiveness institutions of self-organization, it consists in deprivation of their donors from taxes. Although institutions of self-organization are financed mainly by public authorities, they remain independent, because they have opportunity of funding from other sources. German experience showed that the starting point in the system of public services is the understanding of the necessity of paying taxes as acknowledgment of the rights of all members of society. That is why every taxpayer expects to receive public services at the appropriate level. This unwritten rule contributes to a very high level of provision of public services through an adequate level of financing carried out by persons with appropriate competence and qualifications. The example of Portugal discloses the status of self-organization institutions as public benefit organizations, which provides them of advantages, particularly in competition with private sector organizations. However, in the light of practical implementation of the principle of subsidiarity and other elements of decentralization is appropriate to introduce European experience in the domestic soil in the context of attracting self-organization institutions in the scope of public services delivery. The results of the study formulated the main components of a mechanism to ensure effectiveness of the self-organizations institutions in the provision of public services: subsidies of statutory activities; delegation of services; regulatory support; recognition of the status of self-organization institutions as public benefit organizations; limitation of agreements terms.

Keywords: public services; cooperation; public authorities; financing institutions of self-organization

\title{
Европейские практики обеспечения действенности институтов самоорга- низации населения в контексте оказания общественных услуг
}

\author{
Т.В. Серегина \\ seregina.dridu@gmail.com \\ Днепропетровский региональный институт государственного управления Национальной академии \\ государственного управления при Президенте Украины, \\ 49044, Днепр, ул. Гоголя, 29
}

Установлено, что европейские страны достаточно много внимания уделяют необходимости обеспечения действенности институтов самоорганизации населения, так как последние в качестве выразителей общественных проблем могут с ними справиться наилучшим образом и в первую очередь это делается путем оказания общественных услуг. Особенностью европейских практик являются исторически заложенные традиции оказания общественных услуг организациями конфессиональной направленности, которые таким образом реализуют свое призвание в обществе. Трансформации в части субъекта оказания общественных услуг произошли когда в Европейских странах формировалось понятие «государство благосостояния» и государство взяло на себя ответственность за сферу общественных услуг. Основываясь на опыте оказания общественных услуг органами публичной власти, началось формирование новых подходов в части субъекта оказания услуг. Наиболее распространенным на сегодняшний день является привлечение к этому процессу институтов самоорганизации населения. Хотя это не единственный механизм их сотрудничества с публичным сектором, другой состоит в финансировании уставной деятельности, что является наиболее распространенным в Украине. Однако через призму реализации на практике принципа субсидиарности и других элементов процесса децентрализации, а также обеспечения действенности институтов самоорганизации населения, целесообразным выглядит внедрение на отечественном грунте европейского опыта в контексте привлечения институтов самоорганизации населения к сфере оказания общественных услуг. Раскрыто такой вспомогательный способ обеспечения действенности институтов самоорганизации населения как норма, согласно которой организации, которые являются донорами неправительственного сектора, избавлены от необходимости оплаты налогов. На особое внимание заслуживает вопрос признания общественно-полезного статуса институтов самоорганизации населения, что предоставляет им преимущество в конкурентной борьбе с частным сектором. По результатам проведенного исследования сформулировано основные компоненты механизма обеспечения действенности институтов самоорганизации населения в 
сфере оказания публичных услуг: субсидирование статутной деятельности, делегирование услуг, нормативное обеспечение, признание статуса общественно-полезных, ограничение сроков договоров.

Ключевые слова: общественные услуги; публичная власть; финансирование институтов самоорганизации населения

Постановка проблеми. Взятий Україною курс на європейські цінності не тільки надає певні переваги, але також висуває перед суспільством певні вимоги, яких слід дотримуватися. Наприклад стосовно норми щодо дієвості демократичних інституцій, адже в Україні між власне цією нормою та ії реалізацією існує певний простір. 3 одного боку, в ст. 6 Угоди про асоціацію [1] зазначено спільні принципи, серед яких і вищезазначена норма, 3 іншого боку, сучасний стан розвитку суспільства не в повній мірі відповідає реалізації зазначеного.

Аналіз досліджень і публікацій. Питання забезпечення дієвості інститутів самоорганізації населення $є$ достатньо актуальними на сьогоднішній день, коли відбуваються процеси децентралізації. Вони сприяють розширенню прав інститутів самоорганізації населення, передачі їм частини повноважень, а разом 3 тим і обов'язків 3 боку органів публічної влади. Тож закономірним виглядає значна зацікавленість зазначеними питаннями з боку науковців, зокрема таких, як Е. Афонін, В. Бакуменко, М. Гаман, І. Коліушко, Т. Маматова, Т. Мотренко, В. Сороко, В. Толкованов, А.Чемерис та ін. Проте питанням дослідження досвіду зарубіжних країн у контексті забезпечення дієвості інститутів самоорганізації населення достатньо уваги не приділялося, що стало підставою для проведення даного дослідження.

Мета дослідження полягає в визначенні підходів, які застосовуються в зарубіжних країнах, що сприяють забезпеченню дієвості інституцій самоорганізації населення.

Виклад основного матеріалу. В таких європейських країнах, як Велика Британія, Німеччина, Франція та ін. рівень забезпечення дієвості демократичних інституцій можна оцінити за рівнем загального бюджету неурядових організацій. Він складає 3,5 \% ВВП країн, стільки ж або навіть більше, ніж частка сільського господарства [2]. Одразу слід зазначити, що ця цифра не включає в себе даних такого, що набув неабиякого розповсюд- ження, волонтерського руху. Саме на його долю припадає левова частка послуг, що стосуються допомоги під час надзвичайних ситуацій у системі охорони здоров'я або освіти. Звідси можна зробити висновок, що країни Європи не обмежуються одними лише деклараціями, а дійсно спрямовують зусилля на розвиток неурядового сектора.

Попри надзвичайно широкий спектр діяльності неурядового сектора, він, як похідна суспільства, займається вирішенням проблем суспільства, а отже, вся його діяльність, попри всю різноманітність, вміщується в рамках сфери надання суспільних послуг. Проте без відповідної підтримки держави, належного рівня ефективності його діяльності досягти вкрай складно. Враховуючи це, а також ті переваги, що надає залучення інститутів самоорганізації населення до вирішення суспільних проблем [10], європейські країни забезпечують останні вагомою підтримкою держави.

Загальновідомо, що країни Свропи є чи не найбільш обізнаними в сфері надання послуг, яка почала свій стрімкий розвиток з середини XX ст. поряд з появою та закріпленням такого поняття, як «держава добробуту». Це період відновлення Свропи після двох світових війн, коли паралельно з реконструкцією зруйнованих економік країн паралельно відбувалося становлення громадянського суспільства та оформлення його суспільної складової в окрему сферу, відповідальність за що взяла на себе держава. Та саме послуги, бурхливий розвиток яких супроводжував означені процеси, викликають особливий інтерес у контексті дослідження, вони на сьогоднішній день у вищезгаданих країнах становлять більше половини всього національного виробництва.

Але саме суспільним послугам приділяється особлива увага як в силу їхньої значимості, так і в силу складнощів, що виникають в процесі їхнього надання. Значним кроком на шляху розвитку системи надання суспільних послуг була еволюція підходів до статусу суб'єкта-надавача, адже традиційно сфера послуг була прерогативою приватного сектора, сфера суспільних послуг - публічної влади. Та наріжним каменем тут виступило питання 
потреб, про що зазначала ще Маргарет Тетчер [7]: «Воно дозволяє людям задовольняти реальні потреби, а не ті, котрі бачить держава». Тобто інститути самоорганізації населення, які за своєю природою $є$ виразниками суспільних потреб, покликані найкращим чином їх і задовольняти.

У Великій Британії, де принцип дієвості демократичних інституцій реалізується на практиці, передбачено можливість звільнення від оподаткування організацій, за рахунок внесків яких відбувається фінансування інститутів самоорганізації населення. Положення відносно незалежності останніх попри механізм залучення коштів як місцевих, так державних бюджетів є правомочним не тільки для Великої Британії, а й для інших країн $\mathrm{C}_{\text {в- }}$ ропи [8]. В основі лежить можливість інститутів самоорганізації населення для досягнення поставлених цілей залучати ресурси інших джерел.

Окрему увагу слід приділити досвіду Нiмеччини, де негласним правилом $є$ необхідність визнавати права та свободи кожного представника суспільства, тобто бути платником податків 3 тим, щоб і твої права були визнані. Цілком природною виглядає ситуація, що в Німеччині рівень надання суспільних послуг досить високий, адже інститути самоорганізації населення 3 відповідним рівнем фінансування мають змогу наймати все більш оплачуваних працівників. Додатковою перевагою, зокрема в контексті надання соціальних послуг, виступає т. зв. принцип «від допомоги до самодопомоги», що передбачає, залучення до надання соціальних послуг осіб, які проживають на тій самій території, знаходяться в однаковій віковій категорії й т. ін.

У самих витоків залучення інститутів самоорганізації населення до вирішення суспільних питань в Німеччині стояв волонтерський рух, хоча таке визначення там формулювалося як «діяльність на громадських засадах». Певні трансформації відбулися коли суспільні зміни ставили нові виклики, одним 3 найважливіших була необхідність забезпечення належного рівня компетенції, кваліфікації, відповідальності тощо.

На допомогу інститутам самоорганізації населення Німеччини також виступає принцип взаємного доповнення, який включений до Конституції Німеччини й закріплює відносини між державним та неурядовим секто- рами. Актуальною ця норма $\epsilon$ на всіх рівнях державної влади як на рівні федерації, так і на рівні федеральних земель та районів.

Проте тенденціями останніх років $є$ підвищена увага до діяльності інститутів самоорганізації населення [9] - поряд із їхньою роллю, яка все більше зростає, $є$ необхідність забезпечення й належного рівня прозорості їхньої діяльності. Справа в тому, що в Німеччині відсутній єдиний підхід щодо розкриття інформації такими організаціями, в тому числі й відносно використання залучених коштів, здебільшого вони є підзвітними лише перед своїми членами. У цьому зв'язку мова йде про необхідність реформування відносин в цій сфері, в тому числі передбачається внесення змін й до Громадянського кодексу [5]. Пропонується тим організаціям, які отримують кошти від держави, дотримуватися принципу прозорості й робити свої дані публічними.

На окрему увагу заслуговує досвід Бельгії, що відома своїми традиціями залучення неурядового сектора до вирішення суспільних питань, зокрема історія служіння людям, допомоги в їхньому розвитку, а також у випадках коли потрібна стороння допомога. Це історія реалізації християнами-католиками своєї місії, що базувалася на діяльності католицьких благодійних організацій, до речі досить розповсюджена серед інших європейських держав. Суттєвим кроком на шляху реалізації інститутами самоорганізації населення визначених цілей стало створення т. зв. «центрів суспільного добробуту» [4], що представлені в кожному населеному пункті країни. Їхньою метою $\epsilon$ сприяння забезпеченню добробуту кожного громадянина, для зручності створено сайт, де кожен громадянин може знайти для себе всю необхідну інформацію відносно можливостей отримання суспільних послуг. Розподіл послуг за групами на цьому електронному ресурсі виглядає наступним чином:

1. родина (послуги, що надаються при народженні, оформленні шлюбу, у випадку смерті тощо);

2. робота (допомога в пошуку роботи, питання відпустки та кар'єрного зростання, відставки, створення власного бізнесу);

3. справедливість (питання безпеки, прав власності тощо);

4. мобільність (безпека дорожнього 
руху, транспортні засоби, ліцензування);

5. здоров'я (охорона здоров'я, ліки тощо);

6. навколишнє середовище (забруднення, зміна клімату);

7. житло (будівництво, купівля-продаж, оренда);

8. податки (НДС, податок на додану вартість тощо);

9. економіка (торгівля й споживання, економічна інформація);

10. навчання (освіта, дослідження, безперервна освіта).

Хоча номінально такі центри працюють для всіх мешканців населеного пункту, проте здебільшого вони орієнтовані на людей, що потребують допомоги й самостійно не можуть впоратися.

В Австрії однозначного підходу до вирішення питань щодо надання суспільних послуг інститутами самоорганізації населення не існує. Це пов'язане з системою адміністративно-територіального устрою, згідно 3 якою країна $є$ федеративною республікою й складається з 9 федеральних земель. Одним із підходів до співпраці органів публічної влади 3 такими організаціями є субсидіювання (фінансування статутної діяльності організації). Ключовою позицією в даному випадку виступає положення, згідно з яким організація, яка отримує державне фінансування, здобуває перевагу над своїми конкурентами. Таким взаємовідносинам приділено окрему увагу в частині третій Договору про функціонування Європейського Союзу [11]. Згідно 3 Договором, державна допомога в країнах-членах ЄC взагалі заборонена, якщо це не виправдано міркуваннями загального економічного розвитку. Тому в країнах ЄС державна допомога організаціям має відповідати визначеним Законом СС про державну допомогу (ст. 87) правилам, адже державна допомога визначається як перевага в будь-якій формі. У цьому зв'язку передбачено, що державна допомога має надаватися на вибірковій основі, тобто конкретній компанії або галузі чи для компаній, розташованих у певних регіонах. [6] За дотримання цієї норми несе відповідальність Європейська комісія, яка наділена відповідними повноваженнями щодо затвердження заходів 3 надання допомоги, проведення розслідувань відносно відповідності наданої допомоги встановленим правилам, а також прийняття рішень стосовно стягнення державної допо- моги, яка не відповідає встановленим правилам.

Інший спосіб співпраці органів публічної влади 3 інститутами самоорганізації населення - це делегування повноважень, причому, як показує досвід, основним замовником послуг виступає держава, що підкреслює іiї домінантну роль у діяльності останніх. Таким чином, держава $з$ одного боку виступає каталізатором розвитку неурядового сектора, 3 іншого, зумовлює напрямок, в якому він розвиватиметься, адже частка державного фінансування складає близько 53 \% усіх доходів інститутів самоорганізації населення Австрії.

Актуальним виступає також питання конкуренції цих організацій з приватним сектором, особливо, коли мова йде про дитячі садочки, школи, будинки для людей похилого віку тощо. Поза сумнівом, що приватні установи містять чітко визначений перелік послуг, які вони спроможні надавати, проте еквівалентних послуг, коли отримувач послуги сприймається не в якості клієнта, в них немає. Теоретично та практично такі нюанси під час проведення процедур тендерів не враховуються, що певним чином обмежує можливості участі інститутів самоорганізації населення. Певні результати могло б принести введення поняття суспільний інтерес, що створювало б додаткові переваги їм у конкурентному середовищі. Як і в більшості європейських країн, в Австрії велику долю публічних завдань, що припадають на інститути самоорганізації населення, виконують т. зв. конфесійні провайдери, також досить велика частка припадає на організації, які працюють згідно з певною концепцією, наприклад - у сфері дитячої освіти - це організації, що працюють за методикою Waldorf та ін.

Звернення до досвіду Португалії свідчить так само про широку залученість інститутів самоорганізації населення конфесійного спрямування до вирішення публічних завдань. Значний поштовх у даній сфері відбувся після вступу країни до Європейського Союзу, коли вся система надання послуг зазнала змін відповідно до нових стандартів. При цьому виділяються певні особливості, зокрема зважений підхід до залучення організацій неурядового сектора до виконання публічних завдань у контексті визнання їх суспільно корисного статусу. Це надає останнім переваги в конкурентній боротьбі з державними установами та 
приватним сектором. Одним із важливих напрацювань є закріплені вимоги до стандартів послуг, проте визначальною рисою співпраці публічної влади з інститутами самоорганізації населення $\epsilon$ державний аудит, причому організація, де він буде проводитися, обирається випадковим чином, т. зв. рандомний підхід.

Про ефективність запроваджуваної політики говорить загальний результат [3]: у Португалії в 2015 році приблизно 4600 інститутів самоорганізації населення виконували понад 12500 контрактів на надання соціальних послуг (крім медичних); середній розмір контрактів приблизно 25000 євро.

Особливий інтерес представляють механізми фінансування соціальних послуг, причому, щоб інститут самоорганізації населення мав змогу брати участь у конкурсі на державне фінансування, він має набути статус суспільно-корисної організації, що надається центральним органом виконавчої влади, відповідальним за процес передачі.

Як і в більшості європейських країн, договори 3 організаціями неурядового сектора укладаються терміном на один рік, 3 можливістю подальшої пролонгації. Джерелами фінансування виступають як державний бюджет, так і субсидії Європейського Союзу, механізм реалізується шляхом реалізації виплат 3 центрального органу, що носить назву Інститут соціального забезпечення, його регіональні підрозділи уповноважені лише укладати договори 3 інститутами самоорганізації населення. Практики фінансування їхньої статутної діяльності муніципалітетами в Португалії не розповсюджені. Особлива увага приділяється приміщенням інститутів самоорганізації населення, в яких надаються послуги, та достатньому рівню їхнього обладнання, передбачено навіть процедуру, за якої він може отримати державне фінансування на капітальний ремонт або будівництво приміщень, залучення інновацій тощо. Примітним $€$ те, що інституту самоорганізації населення достатньо набути статус суспільно корисної організації й надалі йому непотрібно проходити процедуру ліцензування або сертифікації кожної послуги, що ним надається

Висновки. Досвід європейських країн свідчить про недекларативний підхід до за- безпечення дієвості інститутів самоорганізації населення. Проведене дослідження дозволяє сформулювати такі основні складові механізму забезпечення дієвості інститутів самоорганізації населення у сфері надання публічних послуг:

1. Субсидіювання статутної діяльності, на основі якого традиційно відбувається співпраця інститутів самоорганізації населення з органами публічної влади в Україні.

2. Делегування послуг з огляду на те, що крізь призму реалізації на практиці принципу субсидіарності як елементу децентралізації та забезпечення дієвості інститутів самоорганізації населення, виглядає доцільним запровадження на вітчизняному грунті європейського досвіду в контексті делегування суспільних послуг.

3. Нормативне закріплення, оскільки в країнах Європи виконувати свою суспільну місію організаціям неурядового сектора дозволяє відповідне законодавче підгрунтя. Однією із норм законодавства, що створює додаткові переваги для забезпечення їхньої дієвості, є позбавлення організацій, що їх фінансують, від необхідності сплати податків.

4. Визнання статусу суспільно корисних, що $є$ важливим доповненням до інших механізмів і надає інститутам самоорганізації населення переваги в конкуренції з приватним сектором.

5. Обмеження термінів угод, що складаються в контексті делегування послуг, з урахуванням практики, за якою на сьогоднішній день більшість європейських країн укладає їх терміном на один рік 3 можливістю подальшої пролонгації, що дозволяє підтримувати, 3 одного боку, конкурентне середовище у сфері надання суспільних послуг, з іншого - забезпечувати належний рівень процесів державного й муніципального контролю за організаціями, яким делеговано надання цих послуг.

Подальшого наукового опрацювання потребують елементи механізму забезпечення дієвості інститутів самоорганізації населення у сфері надання публічних послуг у частині визначення вимог щодо імплементації усталених європейських практик у діяльність вітчизняних органів публічного управління i адміністрування. 
БІБЛІОГРАФІЧНІ ПОСИЛАННЯ:

1. Про ратифікацію Угоди про асоціацію між Україною, з однієї сторони, та Європейським Союзом, Європейським співтовариством з атомної енергії і їхніми державами-членами з іншої сторони : Закон України від 16.09.2014 № 1678-VII // Відом. Вер Відом. Верховної Ради України. - 2014. - № 40.

2. Маркетинг соціальних послуг: Навчальний посібник / Під ред. д. ф. н., проф. В. Г. Воронкової. - К.: «Видавничий дім «Професіонал», 2008. - 576 с.

3. Існуючі механізми співпраці органів державної влади з організаціями громадянського суспільства в контексті реалізації Національної стратегії сприяння розвитку громадянського суспільства в Україні 2016-2020. - К.: Ваіте, 2016. - $280 \mathrm{c}$.

4. Belgium.be - Informatie en diensten van de overheid - https://www.belgium.be/nl/familie/sociale steun/ocm

5. Bürgerliches Gesetzbuch. - https://www.gesetze-im-internet.de/bgb/_21.html

6. European Commission - http://ec.europa.eu/competition/state_aid/overview/index_en.html

7. http://www.margaretthatcher.org/document/107352

8. NGOs in International Law: Efficiency in Flexibility? / edited by Pierre-Marie Dupuy, Luisa Vierucci. - Edward Elgar Publishing. -2008 . -288 S.

9. Nur bedingt transparent / Der Tagesspiegel. - 07.07.2015. - http://www.tagesspiegel.de/themen/agenda/arbeit-vonngos-nur-bedingt-transparent/12020726.html

10. Serohina Tetiana. Territorial community: a systematic approach to advance functions of individual elements / Tetiana Serohina // Public administration aspects. - 2016. - № 37 - 38 (11-12). - S. 70 - 75

11. Treaty on the Functioning of the European Union - part three: union policies and internal actions - title vii: common rules on competition, taxation and approximation of laws - Chapter 1: Rules on competition - Section 2: Aids granted by States - Article 107 (ex Article 87 TEC). - Режим доступу : http://eur-lex.europa.eu/legal-content/ EN/ALL/?uri=CELEX:12008E107

\section{REFERENCES:}

1. Pro ratyfikatsiyu Uhody pro asotsiatsiyu mizh Ukrayinoyu, z odniyeyi storony, ta Yevropeys'kym Soyuzom, Yevropeys'kym spivtovarystvom z atomnoyi enerhiyi i yikhnimy derzhavamy-chlenamy z inshoyi storony : Zakon Ukrayiny vid 16.09.2014 № 1678-VII [On ratification of the Association Agreement between Ukraine, on the one hand, and the European Union, the European Atomic Energy Community and their Member States on the other hand the law of Ukraine from 16.09.2014 number 1678-VII]. 2014. Vidom. Ver Vidom. Verkhovnoyi Rady Ukrayiny 40 (in Ukrainian).

2. Voronkovoyi, V. H., 2008. Marketynh sotsial'nykh posluh: Navchal'nyy posibnyk [Marketing Social Services: Textbook]. K.: «Vydavnychyy dim «Profesional». 576 (in Ukrainian).

3. Isnuyuchi mekhanizmy spivpratsi orhaniv derzhavnoyi vlady $\mathrm{z}$ orhanizatsiyamy hromadyans'koho suspil'stva $\mathrm{v}$ konteksti realizatsiyi Natsional'noyi stratehiyi spryyannya rozvytku hromadyans'koho suspil'stva v Ukrayini 20162020 [The existing mechanisms of cooperation of public authorities with civil society organizations in the context of the National Strategy for Civil Society Development in Ukraine 2016-2020]. K.: Vaite. 2016. (in Ukrainian).

4. Belgium.be - Informatie en diensten van de overheid - https://www.belgium.be/nl/familie/sociale_steun/ocm

5. Bürgerliches Gesetzbuch. - https://www.gesetze-im-internet.de/bgb/_21.html

6. European Commission - http://ec.europa.eu/competition/state_aid/overview/index_en.html

7. http://www.margaretthatcher.org/document/107352

8. NGOs in International Law: Efficiency in Flexibility? / edited by Pierre-Marie Dupuy, Luisa Vierucci. - Edward Elgar Publishing. - 2008. - 288 S.

9. Nur bedingt transparent / Der Tagesspiegel. - 07.07.2015. Access: http://www.tagesspiegel.de/themen/agenda/ arbeit-von-ngos-nur-bedingt-transparent/12020726.html

10. Serohina, Tetiana, 2016. Territorial community: a systematic approach to advance functions of individual elements / Tetiana Serohina. Public administration aspects $37-38$ (11-12), $70-75$.

11. Treaty on the Functioning of the European Union - part three: union policies and internal actions - title vii: common rules on competition, taxation and approximation of laws - Chapter 1: Rules on competition - Section 2: Aids granted by States - Article 107 (ex Article 87 TEC). Access: http://eur-lex.europa.eu/legal-content/EN/ ALL/?uri=CELEX:12008E107 